DIW BERLIN

Discussion Papers

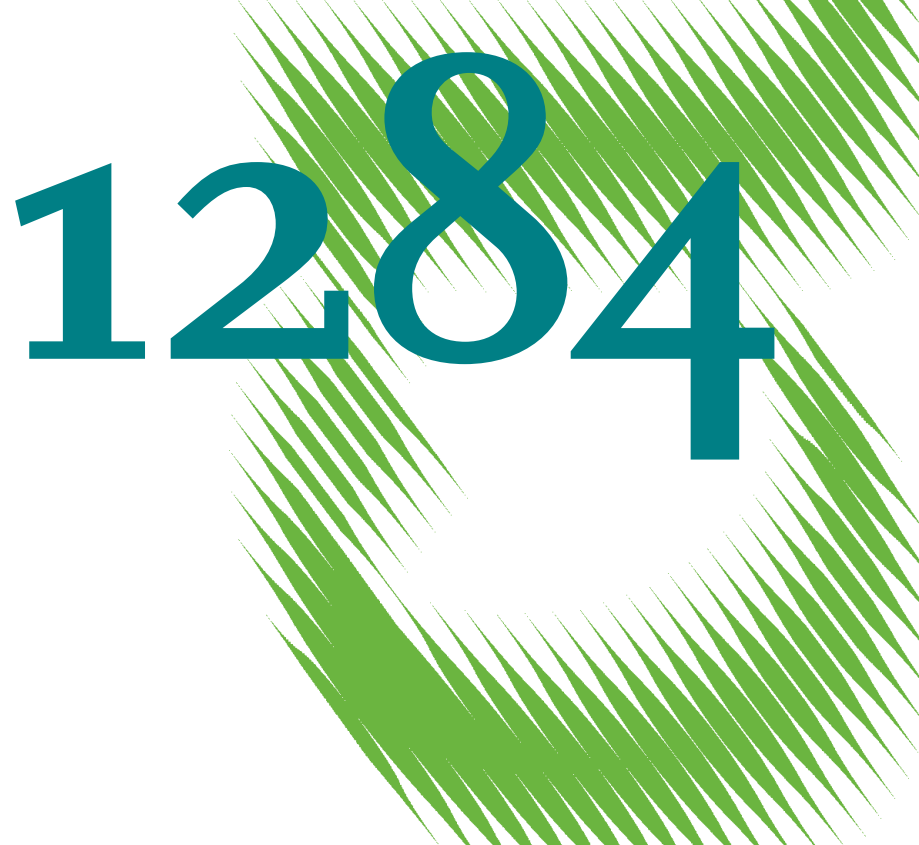

Post-Socialist Transition and the Intergenerational Transmission of Education in Kyrgyzstan 
Opinions expressed in this paper are those of the author(s) and do not necessarily reflect views of the institute.

IMPRESSUM

(C) DIW Berlin, 2013

DIW Berlin

German Institute for Economic Research

Mohrenstr. 58

10117 Berlin

Tel. $+49(30) 89789-0$

Fax +49 (30) $89789-200$

http://www.diw.de

ISSN print edition $1433-0210$

ISSN electronic edition 1619-4535

Papers can be downloaded free of charge from the DIW Berlin website:

http://www.diw.de/discussionpapers

Discussion Papers of DIW Berlin are indexed in RePEc and SSRN:

http://ideas.repec.org/s/diw/diwwpp.html

http://www.ssrn.com/link/DIW-Berlin-German-Inst-Econ-Res.html 


\title{
Post-Socialist Transition and the Intergenerational Transmission of Education in Kyrgyzstan
}

\section{Tilman Brück and Damir Esenaliev}

\begin{abstract}
:
We investigate long-term trends in the intergenerational transmission of education in a low income country undergoing a transition from socialism to a market economy. We draw on evidence from Kyrgyzstan using data from three household surveys collected in 1993, 1998 and 2011. We find that Kyrgyzstan, like Eastern European middle income transition economies, generally maintained high educational mobility, comparable to the levels during Soviet times. However, we find that the younger cohorts, who were exposed to the transition during their school years, experienced a rapid decline in educational mobility. We also document that gender differences in schooling and educational mobility, found among older-aged individuals, disappeared in the younger population.
\end{abstract}

Keywords: intergenerational mobility, educational attainment, gender, transition economy, Kyrgyzstan, Central Asia

JEL Classification: J62, P36, 125

Affiliations: Tilman Brück: Stockholm International Peace Research Institute (SIPRI) and Institute for the Study of Labor (IZA);

Damir Esenaliev: German Institute for Economic Research (DIW Berlin).

Contact author: Damir Esenaliev, email: desenaliev@diw.de; Mohrenstr. 58, 10117 Berlin, Germany; phone: +49 3089789506.

Acknowledgments: For helpful comments we thank Kathryn Anderson, Christine Binzel, Jan Marcus, Matthew Lindquist, Thomas Siedler, and Alina Verashchagina as well as our colleagues Ghassan N. Baliki, Neil Ferguson, Olaf de Groot, Veronika Hümmer, Sindu W. Kebede, Antje Kröger, Tony Muhumuza, Kati Schindler, Susan Steiner, and Marc Vothknecht. Damir Esenaliev would like to thank the Volkswagen Foundation for the support for conducting research during his doctoral study. 


\section{INTRODUCTION}

The collapse of economic output in the transition countries of Eastern Europe and the former Soviet Union markedly increased poverty and inequality. With the distribution of incomes strayed far from egalitarian standards of socialist times (Milanovic, 1999, Milanovic and Ersado, 2008, World Bank, 200ob), the equality of opportunities, including education, is of increasing concern (Micklewright, 1999, UNDP, 2011). Because inequality in income and opportunity tends to transfer across generations (Andrews and Leigh, 2009, Blanden, 2013, Ermisch et al., 2012), the association of socio-economic status between generations strengthened in many transition countries.

However, these findings are mainly based on studies of middle-income post-socialist countries in Europe, such as Bulgaria, Poland and the Baltic countries, which recovered relatively quickly from the economic decline and made substantial development progress during the later phases of transition. There is little research on intergenerational mobility in low income transition countries. Because these countries experienced relatively higher rates of poverty in the early transition, intergenerational links could have strengthened more than in the middle-income transition countries.

We aim to address this knowledge gap by investigating the effect of the transition on intergenerational educational mobility in Kyrgyzstan, a low-income country in Central Asia. We pose three questions in the paper: (1) what is the magnitude of educational intergenerational mobility in Kyrgyzstan; (2) how has the transition affected educational mobility; and, (3) if there is a gender gap in educational mobility? We use three household surveys, collected in Kyrgyzstan in 1993, 1998 and 2011, to approximate for early, mid, and late transition times, respectively. Using the years of schooling of respondents (aged 20-69) and of their parents, we calculate regression and correlation coefficients to infer the dynamics of educational mobility. For the transition effect, we conduct the same analysis for the individuals aged 25-34. Gender analysis is conducted by investigating intergenerational developments separately for men and women.

We find that Kyrgyzstan has maintained strong educational mobility, comparable to the levels in Soviet times. We argue that the expansion of tertiary educational institutions in the last two decades is a reason for high mobility. However, consistent with similar studies based on countries in Eastern Europe, we find a sharp increase in educational association between parents and children in the 2011 data for the population aged 25-34, the generation whose schooling and employment experience was most affected by the transition. This may indicate 
that higher parental socio-economic status may play a more prominent role in children's enrolment at the post-secondary education, while children of less educated parents face fewer opportunities. In addition, we find a gender difference in our estimates that tends to vanish over time. We relate this to the maintenance of gender parity in schooling in Kyrgyzstan since the socialist times.

While our study cannot identify causality, we make three contributions. First, we provide evidence on the effect of the whole cycle of transition to intergenerational transmission using the latest data. Second, addressing the research gap, this is the first detailed study to explore intergenerational mobility in a low income transition country. Third, we analyze the gender dimension of this topic.

The next section discusses the developments in intergenerational mobility in post-socialist countries. Section 3 argues that Kyrgyzstan benefited greatly from the Soviet educational equality policy and presents the recent expansion of tertiary educational institutions. Section 4 presents the data. The methodology part in Section 5 is followed by the presentation of the findings. Section 7 discusses the implications and the limitations of the findings.

\section{INTERGENERATIONAL MOBILITY BEFORE AND DURING THE TRANSITION}

Intergenerational mobility studies - which investigate the extent a socioeconomic status of a young generation is associated with parental background - are important from policy perspective. A higher association of achievements between children and parents brings a discussion whether the policy should to be adjusted to equalize opportunities in a society. In this respect, post-socialist countries represent a fascinating case of societies that achieved a high level of equality, but after the transition to a market system have seen an erosion of this inheritance.

At the onset of transition, the socialist countries were considered relatively egalitarian and mobile societies in international comparison (Atkinson and Micklewright, 1992, Titma and Saar, 1995, Titma et al., 2003). Driven by policies and interventions, equalization in the socialist times covered many areas of life, be it equality in incomes or access to public services, such as healthcare and education (Hanley and McKeever, 1997). Most prominent were efforts to achieve equalization in education, promoted through universal literacy policy and - in the times of mature socialism - by reverse discrimination. These policies and institutional settings 
weaken a 'parent-child' association in educational attainment and promote educational mobility.

The policy of universal literacy, implemented by providing free, but compulsory, education, markedly increased educational achievements in the Soviet Union. The literacy campaign started in the Soviet Union in the early 1930s (Smith, 1997). Prior to World War II, the Soviet Union provided 7-years of compulsory schooling; by the 1960 os 8 years of compulsory schooling was standard. By 1970 around a half of the Soviet Union's population, aged 10 and older, had basic (either complete or incomplete) or higher level of education (Simirenko, 1972). This policy was especially beneficial for Central Asian countries that had low levels of educational achievements before becoming part of the Soviet Union.

The policy of reverse discrimination - promoting children from lower classes into higher education using quotas and other incentives - was another factor that supported equalization of post-secondary schooling attainment (Ganzeboom and Nieuwbeerta, 1999). Although the equalization policy also promoted upward educational mobility in the socialist countries, its effectiveness varied from country to country.

Confirming aims of the socialist system to equalize human capital, one strand of literature finds high educational and social mobility in the socialism period. Titma and Saar (1995) conclude that real equalization of educational opportunities was achieved in the Soviet Union in the last years of its existence, but that regional differences existed in the availability of secondary education schools. Titma et al. (2003) find relatively high occupational intergenerational mobility in the European part of the Soviet Union in the last years of its existence. They claim that the Soviet society, in its final years, was relatively open with a low level of social reproduction. Verashchagina (2012) reports increased educational mobility in her study of 12 transition economies in former Soviet Union and Eastern European countries. However, intergenerational mobility was somewhat lower for younger age cohorts.

Another strand of literature challenges the equalizing efforts of socialist system by pointing to the important role of parental background. A study of the three Baltic countries by Hazans et al. (2008) finds that parental education is an important factor on the propensity to earn a university degree both in Soviet times and during transition. Concordant with this line of literature, Gerber and Hout (2004) look at the occupational mobility in Russia before and after the Soviet era. They argue that the occupational positions did indeed depend on class origins, even in the Soviet times, and that the political and economic transition intensified the 'childparent' association. 
With the transition, most empirical literature tends to find a decline in intergenerational mobility. This decline seems to be affected by both economic and structural changes. The early transition processes, such as deterioration in income, increase in economic inequality, and decline in public expenditures were claimed to be harmful for educational mobility. However, the role of structural reforms that encourage more schooling - such as liberalization and expansion of post-secondary educational institutions and reforming the educational systems to meet the needs of transformed labor markets - covered less in the literature. The paper by Fan et al. (1999) argues that a timely restructuring of educational system in a transition economy to meet labor market needs - is extremely important in order to preserve the stock of human capital, thus ensuring educational continuity between generations. Spagat (2006) develops this concept further and argues that if enough policy efforts are not made to align the educational system with labor markets, the stock of human capital in transition countries will deteriorate and become more similar what is found in middle-income developing countries. Silova et al. (2007) argues that Central Asian countries have already experienced deterioration in publicly funded educational system, and is becoming less effective and less fair.

The early transition years saw a devastating effect on income in a number of transition countries, resulting in high poverty and inequality (Atkinson and Micklewright, 1992, Brück et al., 2010, Milanovic, 1999). Decline of income might force families, particularly the poor households, to reduce investments in education of their children, especially at the tertiary level (World Bank, 2000a). This assumption is found to be true by Gerber (2000), who documents a growing educational stratification in Russia due to declining enrollment in tertiary education of children with lower parental educational background. Compared to children of more educated parents, a higher share of young people with poorer backgrounds opt to enter the labor market earlier due to the worsening living standards and economic hardship associated with the transition.

As lower level of educational achievement of individuals is usually associated with a higher level of poverty, polarization of incomes in transition countries may lead to a widening educational gap over generations. A multi-country study by Andrews and Leigh (2009) finds a negative link between inequality and intergenerational mobility: individuals in countries with higher levels of income inequality experienced less mobility.

One way to mitigate the economic and social exclusion of poor households is to provide social support. However, during the early transition years public expenditures for social support and public schools declined in most countries. This mostly affected the worse-off households that 
previously benefited from free schooling. For example, Hertz et al. (2009) document a strong decline in education expenditures in Bulgaria that led to lower enrollment rates for children of less-educated parents.

Liberalization of the educational system in the transition context may drive educational mobility in both directions. Abolishment of the planning nature of the previous system and relaxation of the regulation led to an expansion of tertiary educational institutions. This process is a mechanism that positively affects intergenerational educational mobility as more students can pursue post-secondary studies. However, as new educational institutions are financed mainly by tuition fees, it may reduce opportunities for children from poorer households. This argument, however, does not seem to have played out in practice so far. Tertiary enrollment has grown quite rapidly in the transition countries that have made progress with transitional reforms (World Bank, 2oooa).

\section{TRANSITION AND EDUCATION IN KYRGYZSTAN}

After the dissolution of the Soviet Union, Kyrgyzstan experienced a dramatic decline in national output and living standards. Despite having recovered economic growth since mid1990s, the country still remains a low-income economy with a third of the population classified as poor (Table 1). Likewise, in the early years of transition the country experienced a sharp more than double - rise in inequality, associated largely with the early transformational consequences, such as wage arrears and erosion of social safety nets (Mitra and Yemtsov, 2006). Once economic growth resumed, inequality returned to a relatively low level by international standards.

Table 1: Kyrgyz Republic: Economic growth, inequality and education Average per period

\begin{tabular}{lrrrrrr}
\hline & $1988-89$ & $1990-94$ & $1995-99$ & $2000-04$ & $2005-09$ & $2010-11$ \\
\hline Real GDP per capita, 1989=100 & 100 & 80 & 57 & 66 & 78 & 85 \\
GNI per capita (Atlas method), USD & $\ldots$ & 447 & 360 & 318 & 638 & 860 \\
Income Gini index, \% & 26.0 & 53.7 & 36.0 & 33.2 & 37.0 & $\ldots$ \\
& & & & & 86.2 & 86.1 \\
Gross secondary school enrollment, \% & 103.6 & 97.1 & 80.0 & 86.4 & 86.2 & 41.3 \\
Gross tertiary school enrollment, \% & 28.1 & 24.1 & 24.9 & 39.9 & 45.7 & 5.8 \\
Public spending on education, \% of GDP & $\ldots$ & 5.6 & 4.6 & 4.2 & 5.8 & 5.8 \\
\end{tabular}

Source: World Development Indicators (2013) 
Educational attainment in Kyrgyzstan in the second half of the $20^{\text {th }}$ century progressed considerably thanks to the Soviet Union's universal schooling policy and investments. The literacy rate in Kyrgyzstan increased from 15 percent in 1926 (Lorimer, 1946) to nearly 100 percent by the time of the country's independence in 1991. Education in Soviet times was free at all levels, including higher education (Mertaugh, 2004). Access to higher education, though, was restricted to about one-fifth of secondary school graduates in accordance with the planning nature of the Soviet system (Karklins, 1984).

The structure of the educational system in Kyrgyzstan has largely remained unchanged during the transition. The secondary school system is based on 4-5-2 year scheme. The first, primary level, up to $4^{\text {th }}$ grade, is attended by children aged 7 to 10. The next level, basic education, lasts through grade 9 , which is a minimum compulsory school level ${ }^{1}$. After gth grade, students have a choice to continue studying at vocational institutions, or to stay for two more years in secondary school in order to qualify for enrollment in universities ${ }^{2}$.

Contrary to experiences of some transition countries, the Kyrgyz government was able to maintain a pre-transition share of public spending on education (World Bank, 2004). This prevented the closure of schools and decline in enrollment; except at the pre-school level (Anderson and Heyneman, 2005, Falkingham, 2005, Mogilevsky, 2011). However, public expenditures on education mainly covered wages of teachers, while other important components of learning, such as textbooks, school infrastructure and teacher training, were underfinanced (Mertaugh, 2004). These factors, along with a shortage of teachers of important subjects, are thought to be main causes of the deterioration in the quality of education ${ }^{3}$. Despite the perceived decline in the quality of education, enrollment rates at the tertiary level have tripled, driven mainly by expanded private universities.

The deregulation of the tertiary education system led to an increased number of private universities, and, correspondingly, students. There were 52 universities in mid-2011; a five-fold increase since Soviet times. As a result, gross enrollments in higher education institutions increased from 10 percent of corresponding age cohort in the beginning of $1990 \mathrm{os}$ to

\footnotetext{
${ }^{1}$ Compulsory secondary schooling was reduced from 11 to 9 years in 2003 in order to ease pressure on public expenditures. It seems that few opted to discontinue studying after the basic level (illustrated in Table 1), driven, probably, by a wider choice of and easier access to tertiary institutions.

${ }^{2}$ However, the vocational track allows to enter to universities after completion of vocational study.

${ }^{3}$ For illustration, 15-year-old students from Kyrgyzstan performed worst out of 65 participating countries on the OECD PISA test conducted in 2009 (OECD, 2010).
} 
approximately 48 percent in mid-20oos (OECD, 2010). This process allowed the child-parent schooling gap in Kyrgyzstan - that was converging in socialist times - to be maintained in transition times. Likewise, the share university educated in adult population increased from 11 percent in 1990 to 16 percent in 2009 (NSC, 2009b) (also see Figure A.1 in Appendix).

This high university enrollment is driven by aspirations for social status and of greater returns (Roberts et al., 2009). Yet, a university diploma is no guarantee of employment, as there is clearly an excess supply of university graduates in the labor market (DeYoung, 2011) with skills that do not meet the expectations of prospective employers (World Bank, 2012). Given this mismatch, the youth unemployment rate and employment in informal sector are the highest in the labor market compared to older age cohorts (NSC, 2009a, NSC, 2012).

Examining intergenerational mobility using educational attainments, but not income or other economic status, is justified, at least, for two reasons. First, in the context of a low-income transition economy, the data on earnings and income are not reliable for both children and parents generations. Second, there are no panel data long enough that can measure the socioeconomic status of both children and parents at similar productive ages, thus imposing utilization of recall data. In this respect, educational attainments are more robust measures of socioeconomic status not prone to large measurement and recall errors. At the same time, educational mobility highly correlates with income mobility (Holmlund et al., 2011, Solon, 2004), and the results may be suggestive on developments in economic mobility.

\section{DATA}

In this paper we use information on educational attainment of respondents and of their parents from three household surveys. These surveys, collected in 1993, 1998, and 2011 are well positioned to trace the dynamics of educational mobility during the two decades of Kyrgyzstan's transition. First, the 1993 data is the earliest source that approximately represents the demographic structure and educational attainments achieved in the Soviet times. Second, the 1998 data is important in order to take into account the completion of the early structural reforms and of large internal and external migration of population. For illustration, around 14 percent of 1989 population of Kyrgyzstan out-migrated permanently in the following ten years. It is believed that the ethnic groups that migrated (mainly Russians, Ukrainians, and Germans) had higher educational attainment than Kyrgyz and Uzbeks, the two largest ethnic groups 
currently (Abazov, 1999). Finally, the 2011 data is valuable as it includes a young generation that obtained education and joined labor markets during the transition.

The first data source, the 1993 Kyrgyz Multipurpose Poverty Survey (KMPS), is a nationally representative survey designed to measure living standards (NSC, 1993). The sample contains about 2,00o households with 10,00o individuals (Table 2). The migration section of the adult questionnaire contains recall information about the level of parental education. Because we limit our analysis to individuals aged $20-69^{4}$, we exploit 3,987 child-parent observations.

Table 2: Summary of datasets

\begin{tabular}{|c|c|c|c|c|c|c|c|}
\hline \multirow[t]{2}{*}{ Dataset } & \multirow[t]{2}{*}{ Year } & \multicolumn{2}{|c|}{ Original sample size } & \multirow{2}{*}{$\begin{array}{c}\text { Individual- } \\
\text { parent pairs } \\
\text { used }\end{array}$} & \multicolumn{3}{|c|}{ of which (\% of individuals aged 20-69) } \\
\hline & & $\begin{array}{c}\text { \# of } \\
\text { households }\end{array}$ & $\begin{array}{c}\text { members aged } \\
18+\end{array}$ & & Females & $\begin{array}{c}\text { Urban } \\
\text { residents }\end{array}$ & $\begin{array}{c}\text { Ethnic } \\
\text { Russians }\end{array}$ \\
\hline KMPS & 1993 & 1,933 & 5,018 & 3,987 & 52.6 & 39.4 & 19.5 \\
\hline KPMS & 1998 & 2,946 & 8,653 & 7,345 & 52.7 & 40.5 & $19 \cdot 4$ \\
\hline $\mathrm{LiK}$ & 2011 & 2,861 & 8,151 & 6,385 & 52.5 & 37.0 & 8.9 \\
\hline
\end{tabular}

Sources: KMPS 1993, KPMS 1998, LiK 2011

Note: 1998 indicators are weighted

The second data source, the 1998 Kyrgyz Poverty Monitoring Survey (KPMS), is a nationally representative household survey with a sample of 3,00o households (NSC, 1998). The family module comprises retrospective questions about parental education and sector of occupation. We examine 7,345 parent-child pair observations. The third data source is the second wave of the panel household survey "Life in Kyrgyzstan", collected in 2011 (Brück et al., 2013). This nationally representative survey collected data from 2,86o households with information about 8,151 adult members. The family module of the survey includes information about parental education and occupation. The available number of respondent-parent observations is 6,385 .

Data collection of all three surveys was done in the same period (October-November). We apply sample weights to the 1998 dataset as its sample was not proportional to the population. The three data sources are comparable on gender and locational dimensions, and seem to accurately reflect national level ethnic composition changes.

\footnotetext{
${ }^{4}$ In addition to including mostly working aged population, the choice of this particular age cohort allows us to address measurement errors associated with recall information of old-aged respondents and censored nature of educational information of currently studying respondents at age below 20.
} 
The analysis is conducted using years of schooling of respondents (children generation) and of their parents. For children we use reported cumulative years of secondary and post-secondary schooling available in the 1998 and 2011 surveys. In the 1993 data, only the reported years of secondary schooling is available; we transform the reported post-secondary education category to years of schooling based on time needed to complete this schooling (Table A.3 in Appendix). Except for the parents who resided with their children and thus reported own years of schooling, this counting procedure was also applied to calculate the years of schooling of nonresident parents in all three data sources. This approach potentially leads to some inaccuracies, such as fewer years of schooling for repeaters, dropped students, and holders of more than one post-secondary education. The other issue is different years of schooling associated with presumably the same level of education: from the prospective of the current educational system, some parents may be assigned more years of schooling than they have in fact studied. Nevertheless, the years of schooling of both children and parents seems to fit well across three datasets (if compared using common age cohort of children born in 1942 to 1976, the difference in parental schooling was $0.2-0.6$ years between the datasets).

We do not exclude individuals who were studying at the time of the surveys. Instead, we calculate the years of post-secondary schooling by distracting one year from the current grade of an enrolled individual. It is a compromise solution to lessen a measurement bias from the two extremes: 1) dropping the enrolled individuals from the analysis, or 2) including them by counting only the last completed education. In general, the share of enrolled individuals among aged 20-24 was 8, 10 and 22 percent, respectively, in 1993, 1998, and 2011. The share of enrolled among aged 25-34 was less than 2 percent in all three datasets, and nearly zero for the other older age cohorts. In the sensitivity analysis we show the results with the enrolled individuals excluded.

We use average years of schooling of both parents in majority of our analysis. While a "fatherson" pair is a yardstick in most intergenerational mobility studies, we follow the approach of a number of papers (Hertz et al., 2007, Verashchagina, 2012) by considering both female and male individuals and compare their years of schooling to the average years of schooling of both parents. If educational information of one of the parents is missing, we assign him/her the educational information of the other parent. This approach is justified given the low share of individuals with partial parental information ${ }^{5}$ and a high degree of educational assortative

\footnotetext{
${ }^{5}$ In KPMS 1993, 11 percent of cases lacked information on one of the parent's education. In KMPS 1998, and LiK 2011, the number of missing observations for one of the parents' education constituted, respectively, 1.5 and 5.1 percent of the sample used (see also Table A.2 in Appendix).
} 
mating among the parents (correlation in years of schooling of the parents ranges from 0.76 to 0.79 in the three datasets). For a robustness check, we conduct the analysis using only observations where both parents' education is available.

The data demonstrate a remarkable increase in educational attainments in Kyrgyzstan over 70 years. Figure 1 - which depicts the average years of schooling of the respondents and of their parents in the three surveys - demonstrates that the schooling of the children increased from seven years to about 12 years. The schooling of parents progressed more rapidly and grew from about two years to 11 years. Accordingly, the educational gap between the children and parents declined from around five years to one year.

Figure 1: Years of schooling of respondents and of their parents

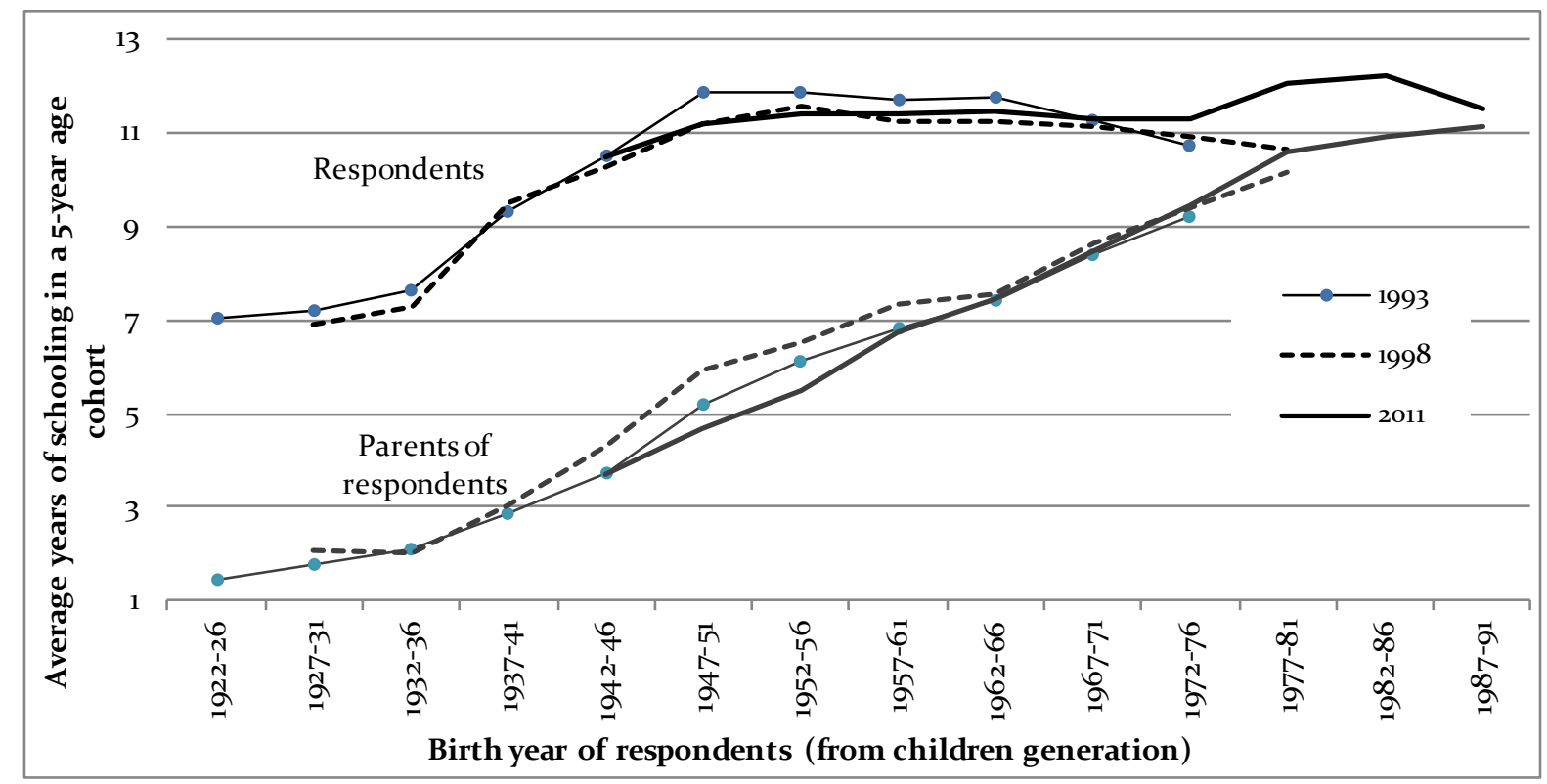

Sources: KMPS 1993, KPMS 1998, LiK 2011

Note: 1998 numbers are weighted.

Table A.6 in Appendix reiterates an increasing educational attainment in Kyrgyzstan over time and provides some interesting comparisons, such as share of university educated. It also presents the descriptive statistics for the young group of aged 25-34, a group where the share of university educated in 2011 data increased to 27 percent - twice what it was in both the 1993 and 1998 samples. Parental schooling years are on rise in both the total and young samples; the notable feature is reduced variation in parents schooling in 2011 sample, which affects the differences in the indicators of intergenerational transmission.

Comparison of schooling among ethnic groups confirms some common beliefs (Table A.5). First, the schooling of Russians in both children and parent samples is absolutely higher compared to other ethnic groups (except for the parental schooling in 1993). Second, despite 
increased parental schooling, Uzbek children advanced little beyond the parental education, which might be explained by earlier participation in labor markets ${ }^{6}$.

\section{EMPIRICAL APPROACH}

In line with the literature, we estimate two basic indicators of correspondence in schooling between parents and children: a regression coefficient by using OLS and a correlation coefficient. Both indicators measure the degree of educational transmission across two generations: the higher the coefficient of the indicators, the lower is the intergenerational mobility.

Our base OLS regression specification is following:

$$
S^{C}=\beta_{0}+\beta_{1} S^{P}+\varepsilon
$$

where $S^{C}$ is the years of schooling of an individual, $S^{P}$ is the average years of schooling of both parents; superscripts $C$ and $P$ stand for children and parents, respectively. The regression coefficient $\beta$ 1 shows how a one-year increase in the schooling of parents raises the expected schooling of their children. In order to compare the results with the correlation coefficient, we do not control for age of individuals in this specification. The correlation coefficient, $\rho$, is linked to the regression coefficient in the following way:

$$
\rho=\left(\sigma^{P} / \sigma^{C}\right) \beta_{1}
$$

where, $\sigma^{P}$ and $\sigma^{C}$ are the standard deviations of schooling, respectively, of parents and children. Correlation provides the same interpretation of intergenerational transmission; though it measures an association between a one standard deviation change in parents' education and a one standard deviation change in children's education. Both correlation and regression coefficients will match if the standard deviation of years of schooling in two generations are of comparable magnitude. If the dispersion of parental schooling is larger than of children's, then a correlation coefficient will be greater than a regression coefficient.

In order to measure the effect of transition we compare the correlation and regression coefficients for those aged 25-34 in each sample (referred as 'young group'). This group is

\footnotetext{
${ }^{6}$ For instance, in the LiK 2011 data a share of enrolled Uzbeks in the youngest age cohort (aged 20-24) was 5 percent compared to 28 and 24 percent, respectively, for Kyrgyz and Russians.
} 
chosen because these individuals in the 2011 data made decisions and obtained education after 1991, when the transition started in Kyrgyzstan. Individuals from comparable age cohorts from 1993 and 1998 surveys obtained education mostly before the transition ${ }^{7}$. Approximating these periods for "before and after" transition, we may judge on the existence of a transition effect if there are differences in indicators in 2011 compared with those estimates for the two earlier surveys.

To provide an insight on the dynamics of the educational mobility, the analysis is also conducted using five-year age cohort groups. Thus, for each dataset comprising individuals aged 20-69, we form ten age cohort groups.

Gender effect is identified by measuring the correlation and regression coefficients separately for male and female individuals ${ }^{8}$. If there are significant differences in the estimated correlation or regression coefficients, we conclude that there is a gender effect.

We extend regression analysis by controlling for age, ethnicity and location. These variables, available in all three datasets, allow to control for policy changes (pertaining to age groups), cultural norms and labor market participation practices (in case of ethnicity) and location characteristics (such as school quality and labor market features). Equation (1) extends now to

$$
S^{C}=\beta_{0}+\beta_{1} S^{P}+\beta_{3} \text { Age }^{C}+\beta_{4} \text { Ethnicity }^{C}+\beta_{5} \text { Urban }^{C}+\beta_{6} \text { Oblast }^{C}+\varepsilon
$$

In addition, exploiting 2011 data we add to specification (3) information on siblings and extra parental information, namely job position and membership in the Communist party in socialist times. Both variables are served to capture parental income and social status as well as social networks that that may affect educational attainment of children.

\section{RESULTS}

In the following we present the results for total and young samples; then discuss gender differences and dynamics of the mobility using age cohorts. The enrichment of the regression analysis by controlling for additional variables completes this section.

\footnotetext{
7 This 'young group' from the 2011 sample was at age 5-14 in 1991.

${ }^{8}$ The gender effect regression analysis can be also conducted by using a female dummy and its interaction with other covariates. We prefer a separate group analysis.
} 
Both indicators of intergenerational educational mobility in Kyrgyzstan demonstrate improvement over time. The first part of Table 3 shows that both regression and correlation coefficients, calculated for individuals aged 20-69, dropped considerably: the regression coefficient declined from 0.27 in 1993 to 0.17 in 2011, while correlation coefficient changed from 0.39 to 0.28 over the same period. This level of the regression coefficient as a measure of intergenerational mobility is extremely low by international standards (Hertz et al., 2007) (see also Table A.1 in Appendix).

Table 3: The relation between parents' and children's education total sample and the young cohort

\begin{tabular}{|c|c|c|c|c|c|c|}
\hline & \multicolumn{3}{|c|}{ Regression coefficient } & \multicolumn{3}{|c|}{ Correlation } \\
\hline & 1993 & 1998 & 2011 & 1993 & 1998 & 2011 \\
\hline & \multicolumn{6}{|c|}{ Total sample of individuals aged 20-69 } \\
\hline Parental years of schooling & $0.27^{* * *}$ & $0.27^{* * *}$ & $0.17^{* * *}$ & 0.39 & 0.40 & 0.28 \\
\hline Adj.R-squared & 0.15 & 0.16 & 0.08 & & & \\
\hline \multirow[t]{2}{*}{ \# of obs. } & 3,987 & 7,345 & 6,385 & & & \\
\hline & \multicolumn{6}{|c|}{ Sample of individuals aged 25-34 } \\
\hline Parental years of schooling & $0.13^{* * *}$ & $0.20 * * *$ & $0.50 * * *$ & 0.26 & 0.36 & 0.42 \\
\hline Adj.R-squared & 0.06 & 0.13 & 0.18 & & & \\
\hline \# of obs. & 1,176 & 2,064 & 1,622 & & & \\
\hline
\end{tabular}

Sources: KMPS 1993, KPMS 1998, LiK 2011

Note: 1998 results are weighted. The regression specifications do not include any other control variables. Parental education coefficients in the regressions are significant at $1 \%$ level (marked ${ }^{* * *}$ ).

The results for 1998 are not directly comparable with the estimates of Hertz et al. (2007) who use the same data source for Kyrgyzstan. The replication of the results by using the described method of counting the years of schooling and averaging the regression and correlation coefficient for ten cohorts resulted in 0.25 against 0.20 , and correlation at 0.31 against 0.28 . The possible reasons for differences are sample size and the way the years of schooling are derived.

For individuals aged 25-34 we observe rapidly increased association with education of parents (second part of Table 3). Compared with relatively weak intergenerational association in 1993 and 1998, the 2011 outcomes imply that this link has strengthened considerably: one extra year of parental education is now associated with 0.5 additional years of schooling for their children. The correlation based comparisons also support this conclusion, though the extent of the rise was relatively moderate. This finding is consistent with the evidence from Bulgaria (Hertz et al., 2009), where the association in schooling of young population with parental schooling increased rapidly. 
The increased association of child-parent association is even more pronounced, when we conduct the analysis using educational categories. To do so, we regrouped educational categories from the three datasets into five categories: primary and below, basic, secondary, post-secondary professional, and university. We regress years of schooling of children to highest educational category of one of the parents; we also calculate Spearman rank correlation using educational categories for both children and parents. The regression analysis results, presented in Table A.7 in Appendix, demonstrate an increasing association of postsecondary and university education of children and parents. For example, having a university educated parent in 1993 was associated with additional 1.1 years of schooling of children in the young group; this quantity has increased to 2.8 years in 2011. Likewise, Spearman rank correlation results are consistent with the inference of increasing role of parental education for younger age cohorts.

We conduct a number of robustness checks using alternative groupings. For this purpose, we (1) enlarge the young group to aged 20-34, instead of aged $25-34$; (2) consider aged $35-44$ to approximate for the youngest pre-transition age group; (3) exclude the individuals enrolled in post-secondary studies; and (4) exclude the individuals who reported education of only one of either parents (Table A.9 in Appendix). First, inclusion of individuals aged 20-24 in the young group levels down both regression and correlation coefficients due to higher share of the enrolled individuals. However, the magnitude of increase in intergenerational association between 1993 and 2011 for this group was much higher compared to aged 25-34. Second, the analysis of aged 35-44 does not reveal any increase in intergenerational link in education: regression coefficient was relatively flat and low, while correlation was in downward track. Third, exclusion of the enrolled individuals does not alter or marginally raises both regression and correlation coefficients. Finally, the results using only full parental information reveal nearly no difference with the base model outcomes.

To examine the dynamics of educational mobility, we calculate the regression and correlation coefficients individually for ten 5 -year age cohorts. Figure 2 plots separately the regression and correlation coefficients for each age cohort; each of three lines represents the results for one of three datasets. As shown, the regression results for 1993 and 1998 are relatively consistent with each other implying gradual decline in intergenerational association in education from older to younger cohorts. In contrast, the dynamics of the regression coefficient based on 2011 data was ' $U$ '-shaped and relatively low for the oldest seven cohorts; then it increased sharply for the youngest three age cohorts. The dynamics of the correlation coefficient, from the other angle, was consistent with this trajectory when the 2011 data used, though the scale of change was less 
volatile. It is necessary to note that both indicators in the youngest cohort show a decline that is explained by a high share of individuals who are still enrolled and, thus, may have lower than parents - education at the time of the surveys.

\section{Figure 2: Regression coefficients and correlations of schooling across age cohorts}

Regression

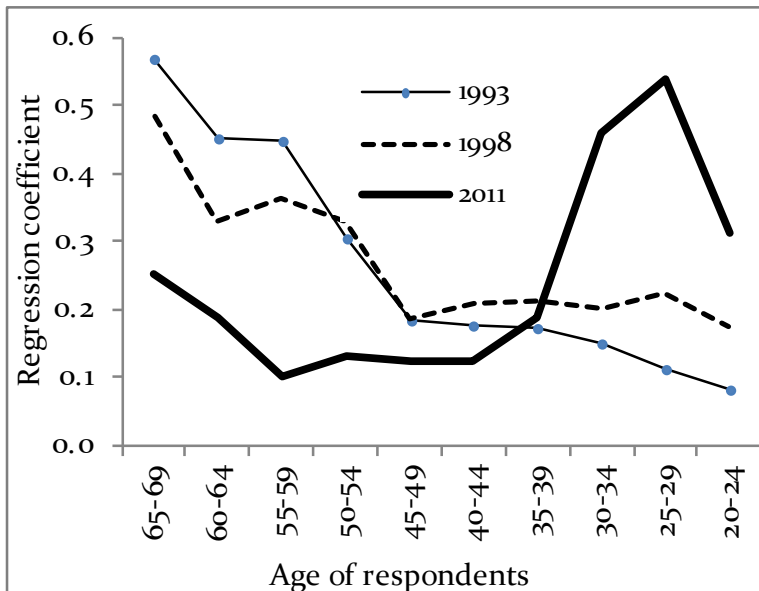

Correlation

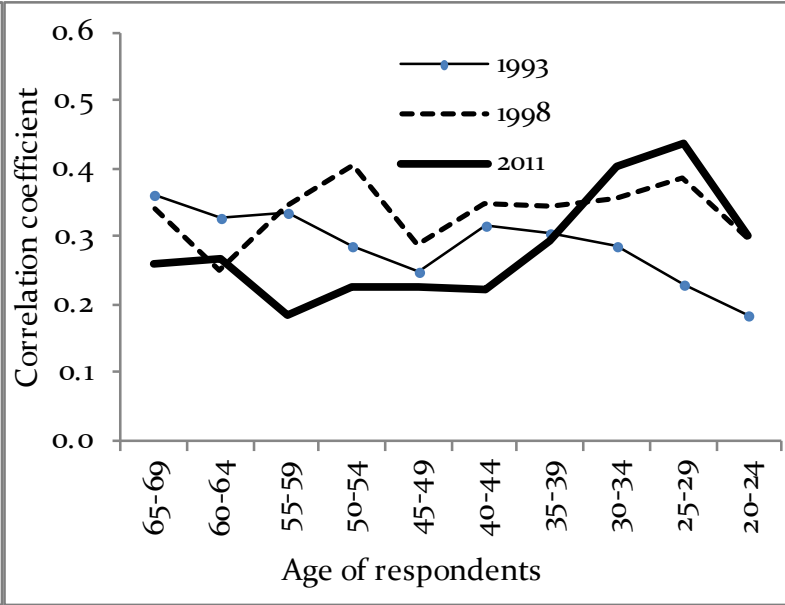

Sources: KMPS 1993, KPMS 1998, LiK 2011

Note: 1998 estimations are weighted. The correlation and regression coefficients are derived for each of the ten cohort group. The age of respondents calculated as of the year of the surveys.

The gender related results for the total sample (in Table 4) indicate that females (from the children generation) are less mobile than males. The difference is statistically and economically significant in the regression results for all three years. This gender gap also holds when correlation coefficients are considered. However, when we analyze gender based mobility in the young group, we do not find large differences in the 1993 or 2011 based on either regression or correlation estimations; only in 1998 data is there a significant difference. Elimination of the gender imbalance has to do with more schooling among women than men, starting with the 1950 generation. In addition, the results of 2011 data suggest that both young females and males - exposed to transition transformation - experienced an increase in intergenerational association in education.

One dimension of gender based analysis is to separately examine a role of maternal or paternal education in relation to the schooling of sons and daughters. Table A.8 shows regression and correlation coefficients for education of sons and daughters versus schooling of fathers and mothers. This disaggregation does not reveal any differences in intergenerational association of education: schooling of both fathers and mothers - analyzed individually - seem to have similar effects on education of children. 
Table 4: Educational mobility by gender

\begin{tabular}{|c|c|c|c|c|c|c|}
\hline & \multicolumn{3}{|c|}{ Regression coefficient } & \multicolumn{3}{|c|}{ Correlation } \\
\hline & 1993 & 1998 & 2011 & 1993 & 1998 & 2011 \\
\hline \multicolumn{7}{|c|}{ Sample of aged 20-69 } \\
\hline Male & 0.21 & 0.20 & 0.13 & 0.33 & 0.33 & 0.22 \\
\hline Female & $0.32++$ & $0.33^{++}$ & $0.21++$ & 0.44 & 0.47 & 0.33 \\
\hline \multicolumn{7}{|c|}{ Sample of aged $25-34$} \\
\hline Male & 0.13 & 0.17 & 0.49 & 0.26 & 0.32 & 0.43 \\
\hline Female & 0.13 & $0.23^{++}$ & 0.50 & 0.25 & 0.41 & 0.41 \\
\hline
\end{tabular}

Sources: KMPS 1993, KPMS 1998, LiK 2011

Note: 1998 results are weighted. The dependent variable is years of schooling of individuals. The right-hand side variable of interest is parental years of schooling; no other control variables are included. The regression coefficients are significant at $1 \%$ level in all years and groups. Statistically different estimates between male and female at 5\% confidence level are marked "++".

We extend the regression analysis above by adding a number of confounding factors that affect schooling of individuals in the children sample. These are age, residency location, and ethnicity. This information is available in all three datasets. Adding age dummies allows for age specific effects - such as changes in compulsory years of schooling - that affected education of individuals beyond parental control to be accounted for. Inclusion of residency information controls for the fact that more educated individuals are likely to live in urban and more populous areas. Ethnicity of individuals seems to play a role in educational attainments, as it was evident from differences in schooling among three major ethnic groups in Kyrgyzstan (see Table A.5 in Appendix).

The second expanded specification, though limited to 2011 data, includes sibling information and parental characteristics such as white collar job positions (high-job position) and membership in the Communist party during socialist times. A larger number of siblings may be associated with lower probability of obtaining post-secondary education if there were credit constraints for parents. A high occupational position of parents incorporates job positions, such as managers and white collar workers. These parental job positions are not strongly linked to higher educational attainment, as our data suggest. A membership of any parent in the Communist party during socialist times indicates not only a relatively higher public decision making position, but also a relatively superior public and economic position after the transition. Membership in communist party was necessary to gain high administrative and managerial positions; after the transition most of these people remained active in politics and extended their power in business (Mikhalev and Heinrich, 1999). As such, parental communist 
background could be a strong predictor of a better off social or economic position of individuals in current times, including education ${ }^{9}$.

First, we comment on the specification that controls for age, location and ethnicity. Confirming our expectations, the regression coefficient is considerably lower for total sample in 1993 and 1998, but not in 2011 (Table 5). This inference also takes place for the young group, but the magnitude of decline is relatively moderate. In terms of dynamics of the intergenerational mobility, our results seem to conform to above evidence that Kyrgyzstan, in general, maintains high educational mobility, but that the schooling of younger population seems to correlate much more with parental background.

Table 5: Regression estimates including covariates

\begin{tabular}{|c|c|c|c|c|c|c|c|c|}
\hline \multirow[b]{2}{*}{ Variable / Year } & \multicolumn{4}{|c|}{ Total sample, aged 20-69 } & \multicolumn{4}{|c|}{ Young sample, aged 25-34 } \\
\hline & 1993 & 1998 & a) 2011 & b) 2011 & 1993 & 1998 & a) 2011 & b) 2011 \\
\hline Parental years of schooling & $0.14^{* * *}$ & $0.17^{* * *}$ & $0.15^{* * *}$ & $0.13^{* * *}$ & $0.10^{* * *}$ & $0.17^{* * *}$ & $0.41^{* * *}$ & $0.37^{* * *}$ \\
\hline Urban & $0.69^{* * *}$ & 0.04 & $0.46^{* * *}$ & $0.37^{* *}$ & $0.58^{* * *}$ & 0.07 & $0.35^{*}$ & 0.26 \\
\hline Bishkek & $0.48^{* *}$ & $1.18^{* * *}$ & $1.01^{* * *}$ & $1.04^{* * *}$ & $0.65^{* * *}$ & $1.18^{* * *}$ & $1.27^{* * *}$ & $1.36^{* * *}$ \\
\hline South & -0.11 & $-0.62 * * *$ & 0.00 & 0.04 & -0.13 & $-0.16^{*}$ & $0.29^{* * *}$ & $0.38^{* * *}$ \\
\hline North, excl. Chui & $0.28^{* *}$ & -0.12 & -0.10 & -0.09 & 0.09 & 0.09 & 0.06 & 0.10 \\
\hline Russian & -0.04 & -0.22 & -0.05 & -0.11 & $-0.57^{* * *}$ & $-0.48^{* * *}$ & -0.01 & -0.17 \\
\hline Uzbek & $-0.56^{* *}$ & $-0.49^{* * *}$ & $-0.84^{* * *}$ & $-0.84^{* * *}$ & $-0.52^{* *}$ & $-0.46^{*}$ & $-1.24^{* * *}$ & $-1.23^{* * *}$ \\
\hline Other ethnic group & $-0.36^{* *}$ & $-0.61^{* * *}$ & $-0.76^{* * *}$ & $-0.74^{* * *}$ & -0.23 & $-0.33^{* *}$ & $-1.07^{* * *}$ & $-1.04^{* * *}$ \\
\hline Siblings & & & & -0.01 & & & & $-0.04^{*}$ \\
\hline Parental high-job position & & & & $0.42^{* * *}$ & & & & $0.33^{* *}$ \\
\hline $\begin{array}{l}\text { Parental membership in } \\
\text { Communist party }\end{array}$ & & & & $0.80^{* * *}$ & & & & $1.21^{* * *}$ \\
\hline Constant & $9.2^{* * *}$ & $9.0^{* * *}$ & $9.1^{* * *}$ & $9.17^{* * *}$ & $10.6^{* * *}$ & $9 \cdot 7^{* * *}$ & $7.2^{* * *}$ & $7 \cdot 5^{* * *}$ \\
\hline Adj.R-squared & 0.33 & 0.30 & 0.18 & 0.19 & 0.11 & 0.19 & 0.25 & 0.25 \\
\hline $\mathrm{N}$ & 3,987 & 7,345 & 6,385 & 6,363 & 1,176 & 2,064 & 1,622 & 1,617 \\
\hline
\end{tabular}

Sources: KMPS 1993, KPMS 1998, LiK 2011

Note: 1998 results are weighted. The dependent variable is the years of schooling of individuals. Kyrgyz and Chui oblast are the reference groups, for ethnicity and regions, respectively. Additionally, all regressions include age dummies. The regression coefficients are significant at $1 \%$ level when marked ${ }^{\prime * * * '}$; at $5 \%$ level when marked '**'; and at $10 \%$ level when marked '*'. Standard errors are clustered at strata level.

\footnotetext{
${ }^{9}$ In LiK 2011 data about three percent of individuals reported to have a parent who was a Communist party member in the socialist times.
} 
In respect to location, city residents have in average more schooling that rural residents; however, this effect is not significant in 1998 data. Individuals living in capital city Bishkek have 0.5-1.4 more years of schooling compared to population in Chui oblast. Among regions, the residents of South oblasts seem to have less schooling in 1993 and 1998 datasets; however, this difference is opposite in 2011 data, especially in the young group.

Ethnicity seems to play a prominent role in educational attainments in Kyrgyzstan. Whilst lower educational level among Uzbeks has been a broadly known fact, the fact that Russians have, on average, slightly less schooling than Kyrgyz - though significant only for young group in 1993 and 1998 - is somewhat surprising.

Interesting insights emerge when we control for siblings and parental high job positions and Communist party membership. There is a strong association of parental job position and Communist party membership for educational attainment of their children (column "(b) 2011" in Table 5). These two parental characteristics in both total and young sample are more important to the educational attainment of children than parental education. For instance, parental Communist party membership is associated with an additional o.8 years of children's schooling in total sample, but even more in the young sample. Number of siblings seems to play some negative role for educational attainment for children in the young age group, although the effect is only marginally significant.

\section{DISCUSSION AND CONCLUSION}

This paper contributes to the research on intergenerational mobility in transition and low income countries by considering the case of Kyrgyzstan. We find that the population aged 2069 in 2011 maintained high educational mobility over the twenty years of transition. For a lowincome country that experienced a sharp decline in living standards and rise in income inequality, this outcome is surprising. This contrasting result can be associated, among other factors, to an expanding number of higher education institutions, which allowed a greater share of secondary school graduates to pursue university education.

We conclude that the dynamics of intergenerational transmission of education in Kyrgyzstan is similar to other post-socialist countries; however, the degree of intergenerational mobility is particularly high compared to both transition and low income countries (Table A.1). In light of these findings, what may be the drivers of high educational mobility in Kyrgyzstan? Partly, the answer lies in the relatively scattered distribution of educational attainments. Kyrgyzstan 
shares with the low-income economies the characteristics of its older population having an extremely low level of schooling. In the study by Hertz et al (2007), parental schooling in the two oldest age cohorts in Kyrgyzstan is 1.5 years $^{10}$, a number that is far below the average of 6.3 years across all transition countries covered (see Table A.1). However, the educational attainment of the youngest parents and the youngest children practically converged to the levels of Eastern European countries. As illustrated in Figure 1, after 2000 Kyrgyzstan reached a point when both parents and children had equally advanced educational attainment. Thus, this evidence led us to conclude that Kyrgyzstan, and broadly Central Asian countries, are unusual in terms of intergenerational mobility.

The gender analysis reveals that females tend to experience lower intergenerational mobility than males in Kyrgyzstan. However, this gender difference in educational transmission is mainly driven by older-aged individuals as this disparity does not exist in younger cohorts. As in many post-socialist countries, this finding points out to improved gender parity in educational attainment in Kyrgyzstan.

High intergenerational educational mobility in Kyrgyzstan is inherently linked to the legacy of Soviet educational investments and equalization policies. However, with the transition we observe an increase in intergenerational transmission of education for young population as our 2011 estimates for the individuals aged 25-34 indicate. While this age group experienced expansion of higher education system, the results are suggestive about growing role of parental background, including education and social status.

Does this finding imply that role of parental background will increase in the future? The literature suggests three drivers of change in intergenerational mobility: the equalizing nature of public expenditure on education, development in economic inequality, and returns to education (Blanden, 2013, Verashchagina, 2012).

Two equalizing mechanisms - compulsory schooling and public expenditures - facilitate relative equality in access to basic and secondary education in Kyrgyzstan. However, as previous studies document, a growing number of students were not completing secondary schooling (Anderson and Heyneman, 2005, Micklewright, 1999). The differences in opportunities became more evident at the post-secondary level, where equalizing institutions of the socialist system were no longer in place and the sector is dominated by private

\footnotetext{
${ }^{10}$ In our study, years of parental schooling of the oldest age cohort (in children group) were respectively $1.6,1.7$ and 3.7 years in 1993, 1998, and 2011 surveys.
} 
institutions. At the same time, increased enrollment in universities is indeed surprising, given rising costs for education and skills mismatch to the needs of labor markets, unless returns to education are sufficiently high. Returns to university education in Kyrgyzstan were, in fact, relatively high in mid-1990s. In particular, Anderson and Heyneman (2005) document that college educated individuals in Kyrgyzstan would expect to earn 17-21 percent higher wages compared to individuals with only basic or lower education. However, given an increased number of university educated individuals in the 2000s, it is relevant to determine whether the wage gap has been maintained; we hypothesize that this return may have been driven down by the increased supply of labor.

As modeled (Solon, 2004) and documented in a number of studies (Andrews and Leigh, 2009, Blanden, 2013), intergenerational mobility is negatively correlated with inequality. As demonstrated in Table 1, income inequality in Kyrgyzstan was very high in the early 199os, but then returned to a moderate level. In this respect, we are not yet able to say much how the income inequality and intergenerational mobility are linked in Kyrgyzstan.

The changing pattern of educational attainments across regions in Kyrgyzstan mirrors migration developments to a great extent. Both external and internal migration seem changing the educational landscape in the country. As discussed before, de-integration of the Soviet Union led to the permanent, disproportionate, migration of better educated people (Abazov, 1999); but the recent permanent and temporary migration also involve a sizable share of skilled population. On the other hand, a rural-urban migration, intensified in the last decade and driven by economic factors, also involves more educated individuals while less educated individuals remain in villages. This internal migration pattern, if continued, may be another factor that will adversely affect intergenerational educational mobility.

We note that young population of non-Kyrgyz ethnic groups seem to lag behind in schooling compared to the Kyrgyz, and it would potentially indicate about existence of some forms of discrimination in segments of labor market where tertiary education is demanded.

Finally, the increasing ratio of people with university education may have a political implication, as it was case in some Arab Spring countries. As more university graduates participate in the labor market either as unemployed, or employed in low-qualification jobs, dissatisfaction with economic and labor market policies may transform governments due to mass demonstration and upraise of youth. In Kyrgyzstan, which experienced change in its political regime in 2005 and 2010 , the educated labor force does not yet seem to be the main factor in the political disruptions, but it may become so in the future. 


\section{BIBLIOGRAPHY}

Abazov, R. (1999) 'Economic Migration in Post-Soviet Central Asia: The Case of Kyrgyzstan', Post-Communist Economies, 11(2): 237-252.

Anderson, K. H. and Heyneman, S. P. (2005) 'Education and Social Policy in Central Asia: The Next Stage of the Transition', Social Policy \& Administration, 39(4):361-38o.

Andrews, D. and Leigh, A. (2009) 'More inequality, less social mobility', Applied Economics Letters, 16(15): 1489-1492.

Atkinson, A. B. and Micklewright, J. (1992) Economic Transformation in Eastern Europe and the Distribution of Income: Cambridge University Press.

Blanden, J. (2013) 'Cross-Country Rankings in Intergenerational Mobility: A Comparison of Approaches from Economics and Sociology', Journal of Economic Surveys, 27(1): 38-73.

Brück, T., Danzer, A. M., Muravyev, A. and Weisshaar, N. (2010) 'Poverty during transition: Household survey evidence from Ukraine', Journal of Comparative Economics, 38(2): $123-145$.

Brück, T., Esenaliev, D., Kroeger, A., Kudebayeva, A., Mirkasimov, B. and Steiner, S. (2013) 'Household survey data for research on well-being and behavior in Central Asia', Journal of Comparative Economics, (http://dx.doi.org/10.1016/j.jce.2013.02.003).

DeYoung, A. J. (2011) Lost in Transition: Redefining Students and Universities in the Contemporary Kyrgyz Republic (Hc): Information Age Publishing.

Ermisch, J., Jäntti, M. and Smeeding, T. M. (2012) From Parents to Children: The Intergenerational Transmission of Advantage: Russell Sage Foundation.

Falkingham, J. (2005) 'The End of the Rollercoaster? Growth, Inequality and Poverty in Central Asia and the Caucasus', Social Policy E Administration, 39(4):340-360.

Fan, C. S., Overland, J. and Spagat, M. (1999) 'Human Capital, Growth, and Inequality in Russia', Journal of Comparative Economics, 27(4): 618-643.

Ganzeboom, H. B. G. and Nieuwbeerta, P. (1999) 'Access to education in six Eastern European countries between 1940 and 1985. Results of a cross-national survey', Communist and Post-Communist Studies, 32(4): 339-357.

Gerber, T. P. (2000) 'Educational Stratification in Contemporary Russia: Stability and Change in the Face of Economic and Institutional Crisis', Sociology of Education, 73(4): 219-246.

Gerber, T. P. and Hout, M. (2004) 'Tightening up: Declining class mobility during Russia's market transition', American Sociological Review, 69(5): 677-703.

Hanley, E. and McKeever, M. (1997) 'The Persistence of Educational Inequalities in StateSocialist Hungary: Trajectory-Maintenance versus Counterselection', Sociology of Education, 70(1): 1-18.

Hazans, M., Trapeznikova, I. and Rastrigina, O. (2008) 'Ethnic and parental effects on schooling outcomes before and during the transition: evidence from the Baltic countries', Journal of Population Economics, 21(3): 719-749. 
Hertz, T., Jayasundera, T., Piraino, P., Selcuk, S., Smith, N. and Verashchagina, A. (2007) 'The inheritance of educational inequality: International comparisons and fifty-year trends', B E Journal of Economic Analysis \& Policy, 7(2).

Hertz, T., Meurs, M. and Selcuk, S. (2009) 'The Decline in Intergenerational Mobility in PostSocialism: Evidence from the Bulgarian Case', World Development, 37(3): 739-752.

Holmlund, H., Lindahl, M. and Plug, E. (2011) 'The Causal Effect of Parents' Schooling on Children's Schooling: A Comparison of Estimation Methods', Journal of Economic Literature, 49(3): 615-51.

Karklins, R. (1984) 'Ethnic Politics and Access to Higher Education: The Soviet Case', Comparative Politics, 16(3): 277-294.

Lorimer, F. (1946) The population of the Soviet Union: history and prospects: AMS Press.

Mertaugh, M. (2004) 'Education in Central Asia with Particular Reference to the Kyrgyz Republic', in Heyneman, S. and DeYoung, A. (eds) The Challenge of Education in Central Asia. Greenwich Connecticut, Information Age Publishing

Micklewright, J. (1999) 'Education, inequality and transition', Economics of Transition, 7(2): 343-376.

Mikhalev, V. and Heinrich, G. (1999) 'Kyrgyzstan: A Case Study of Social Stratification', Working Papers Series No.164. UNU World Institute for Development Economics Research.

Milanovic, B. (1999) 'Explaining the increase in inequality during transition', Economics of Transition, 7(2): 299-341.

Milanovic, B. and Ersado, L. (2008) 'Reform and Inequality During the Transition: An Analysis Using Panel Household Survey Data, 1990-2005', Policy Research Working Paper Series Washington D.C., The World Bank.

Mitra, P. and Yemtsov, R. (2006) 'Increasing Inequality in Transition Economies: Is There More to Come?', Policy Research Working Paper. World Bank.

Mogilevsky, R. (2011) 'Public Expenditures on Education and Health in the Kyrgyz Republic before and during the Global Crisis'. CASE-Center for Social and Economic Research.

NSC (1993) 'Kyrgyzstan Multipurpose Poverty Survey (KMPS) ', Ref. KGZ_1993_KMPS_vo1_M. National Statistical Committee of the Kyrgyz Republic and the World Bank. Dataset downloaded from www.microdata.worldbank.org on June 15, 2011.

NSC (1998) 'Poverty Monitoring Survey (KPMS) ', Ref. KGZ_1998_KPMS_vo1_M. National Statistical Committee of the Kyrgyz Republic and the World Bank. Dataset downloaded from www.microdata.worldbank.org on June 23, 2011.

NSC (2009a) 'Employment and Unemployment in 2008'. Bishkek, National Statistical Committee of the Kyrgyz Republic.

NSC (2009b) 'Population and Housing Census of the Kyrgyz Republic of 2009'. Bishkek, National Statistical Committee of the Kyrgyz Republic.

NSC (2012) 'Employment and Unemployment in 2011'. Bishkek, National Statistical Committee of the Kyrgyz Republic. 
OECD (2010) Reviews of National Policies for Education: Kyrgyz Republic 2010: OECD Publishing.

Roberts, K., Kamruzzaman, P. and Tholen, J. (2009) 'Young people's education to work transitions and inter-generational social mobility in post-soviet central Asia', Young, $17(1): 59-80$.

Silova, I., Johnson, Mark S. and Heyneman, Stephen P. (2007) 'Education and the Crisis of Social Cohesion in Azerbaijan and Central Asia', Comparative Education Review, 51(2): 159-180.

Simirenko, A. (1972) 'From Vertical to Horizontal Inequality: The Case of the Soviet Union', Social Problems, 20(2): 150-161.

Smith, J. (1997) 'The Education of National Minorities: The Early Soviet Experience', The Slavonic and East European Review, 75(2): 281-307.

Solon, G. (2004) 'A model of intergenerational mobility variation over time and place', in Corak, M. (ed) Generational Income Mobility in North America and Europe, pp. 38-47. Cambridge, Cambridge University Press.

Spagat, M. (2006) 'Human capital and the future of transition economies', Journal of Comparative Economics, 34(1): 44-56.

Titma, M. and Saar, E. (1995) 'Regional Differences in Soviet Secondary Education', European Sociological Review, 11(1): 37-58.

Titma, M., Tuma, N. B. and Roosma, K. (2003) 'Education as a Factor in Intergenerational Mobility in Soviet Society', European Sociological Review, 19(3): 281-297.

UNDP (2011) 'Beyond Transition: Towards Inclusive Societies', Regional Human Development Report. Bratislava, UNDP Regional Bureau for Europe and CIS.

Verashchagina, A. (2012) 'Education and Socioeconomic Mobility in Post-Communist Countries', in Parodi, G. and Sciulli, D. (eds) Social Exclusion, pp. 67-91. Physica-Verlag HD.

World Bank (2000a) 'Hidden Challenges to Education Systems in Transition Economies', in Berryman, S. E. (ed). Washington D.C., World Bank, Europe and Central Asia Region.

World Bank (200ob) Making transition work for everyone: poverty and inequality in Europe and Central Asia: World Bank.

World Bank (2004) 'Kyrgyz Republic: Public Expenditure Review '. World Bank.

World Bank (2012) 'Skills, Not Just Diplomas: Managing Education for Results in Eastern Europe and Central Asia', in Bank, T. W. (ed). Washington, D.C. , The World Bank. 


\section{APPENDIX}

\section{FIGURES}

Figure A.1: Educational attainment of population aged 15+

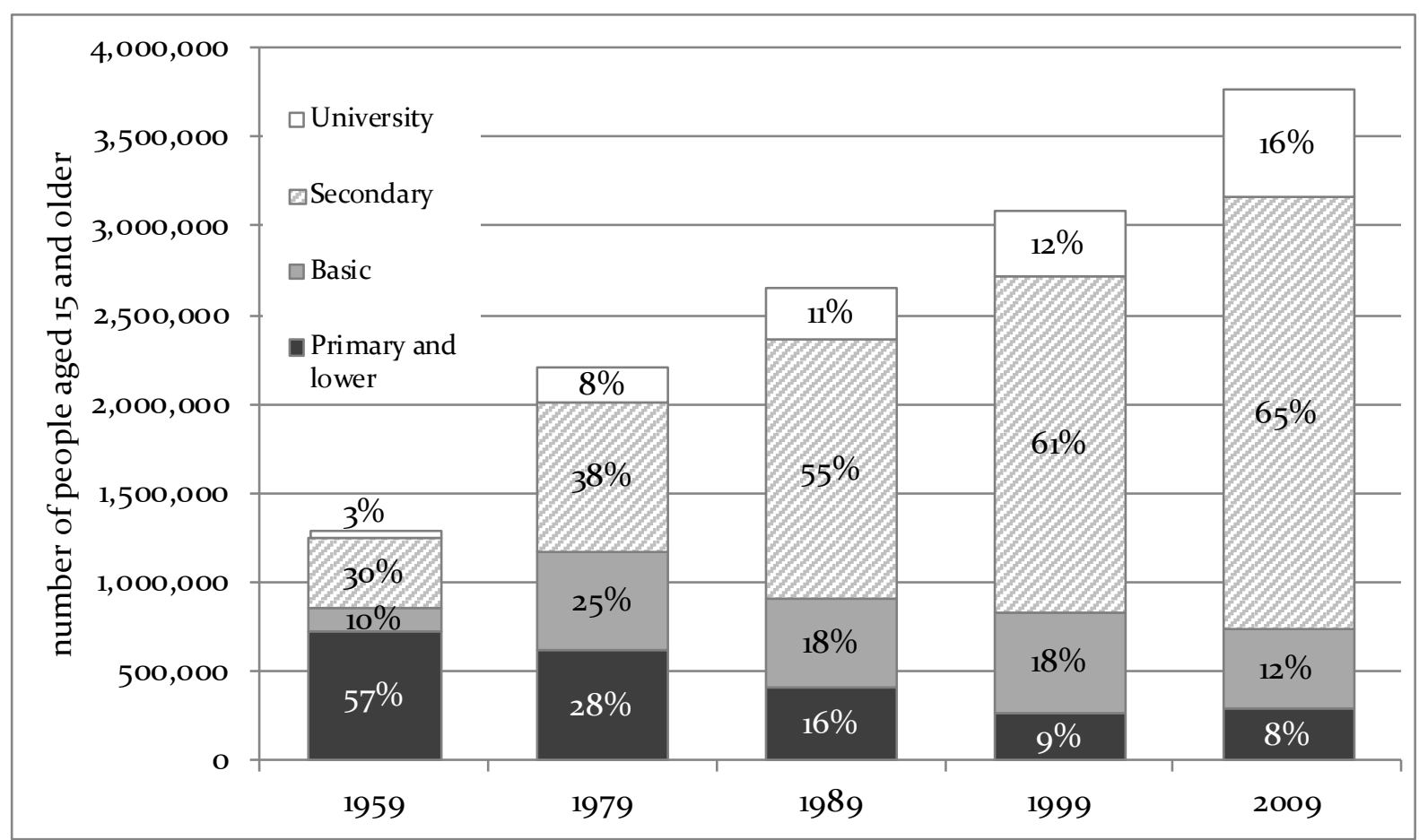

Source: National Statistics Committee, Population Census data from the respective years Note: Shares of educational categories sum up to 100 percent. 


\section{TABLES}

Table A.1: Countries ranked by average parent-child correlation in education individuals aged 20-69

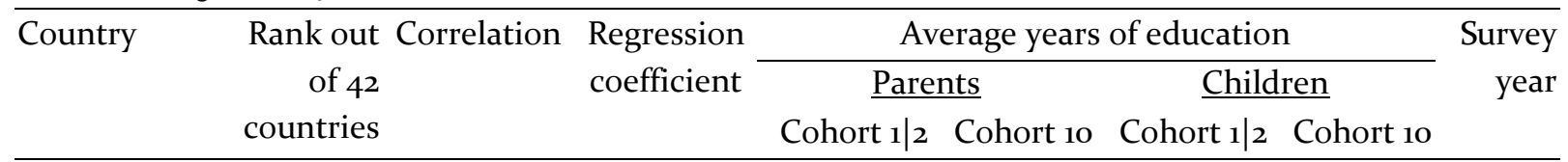

\section{Low-income countries}

$\begin{array}{lllllllll}\text { Bangladesh } & 28 & 0.38 & 0.58 & 0.8 & 2.9 & 2.1 & 5.9 & 1996 \\ \text { Nepal } & 33 & 0.35 & 0.94 & 0.1 & 1.4 & 0.7 & 5.5 & 2003 \\ \text { Ethiopia } & 42 & 0.10 & 0.75 & 0.0 & 0.3 & 0.1 & 3.1 & 1994\end{array}$

Lower middle income countries

$\begin{array}{lrlllllll}\text { Indonesia } & 8 & 0.55 & 0.78 & 0.8 & 5.1 & 2.6 & 9.1 & 2000 \\ \text { Vietnam } & 20 & 0.40 & 0.58 & 0.9 & 5.4 & 3.5 & 7.3 & 1998 \\ \text { Ghana } & 25 & 0.39 & 0.71 & 0.6 & 4.8 & 2.5 & 8.1 & 1998\end{array}$

\section{Transition countries}

$\begin{array}{lrrrrrrrr}\text { Slovenia } & 10 & 0.52 & 0.54 & 6.8 & 10.4 & 8.9 & 12.5 & 1998 \\ \text { Hungary } & 12 & 0.49 & 0.61 & 6.7 & 11.4 & 9.6 & 12.0 & 1998 \\ \text { Estonia } & 23 & 0.40 & 0.54 & 6.2 & 10.9 & 11.4 & 13.0 & 2004 \\ \text { Ukraine } & 26 & 0.39 & 0.37 & 5.6 & 12.0 & 10.4 & 12.9 & 2004 \\ \text { Poland } & 31 & 0.43 & 0.48 & 5.5 & 9.6 & 8.6 & 11.9 & 1994 \\ \text { Czech Rep. } & 34 & 0.37 & 0.44 & 9.3 & 12.0 & 11.8 & 12.4 & 1998 \\ \text { Kyrgyzstan } & 40 & 0.28 & 0.20 & 1.5 & 10.0 & 6.6 & 10.6 & 1998\end{array}$

Source: Adapted from Hertz et al. (2007)

Table A.2: Sample formation

\begin{tabular}{|c|c|c|c|c|}
\hline & KMPS 1993 & KPMS 1998 & LiK 2011 & Treatment \\
\hline Total sample of individuals aged $18+$ & 5,018 & 8,653 & 8,151 & \\
\hline Younger than 20 or older than 69 & 610 & 1,150 & 1,021 & Dropped \\
\hline Sub-sample of individuals aged 20-69 & 4,408 & 7,503 & 7,130 & \\
\hline No education information & 8 & 74 & 37 & Dropped \\
\hline $\begin{array}{l}\text { Individuals aged } 20-69 \text { with education } \\
\text { information }\end{array}$ & 4,400 & 7,429 & 7,093 & \\
\hline $\begin{array}{l}\text { No information on the education of either } \\
\text { parent }\end{array}$ & 413 & 84 & 708 & Dropped \\
\hline Final sample used in the analysis & 3,987 & 7,345 & 6,385 & \\
\hline $\begin{array}{l}\text { Education information for one parent is } \\
\text { missing }\end{array}$ & 451 & 111 & 324 & $\begin{array}{l}\text { Assigned the } \\
\text { other parent } \\
\text { education }\end{array}$ \\
\hline
\end{tabular}

Sources: KMPS 1993, KPMS 1998, LiK 2011 
Table A.3: Calculation of the years of schooling

\begin{tabular}{|c|c|c|c|c|c|}
\hline \multicolumn{2}{|l|}{$1993^{1}$} & \multicolumn{2}{|l|}{$1998^{1}$} & \multicolumn{2}{|l|}{$2011^{1}$} \\
\hline Educational categories & $\begin{array}{c}\text { Years of } \\
\text { schooling }\end{array}$ & $\begin{array}{l}\text { Educational } \\
\text { categories }\end{array}$ & $\begin{array}{c}\text { Years of } \\
\text { schooling }\end{array}$ & $\begin{array}{l}\text { Educational } \\
\text { categories }\end{array}$ & $\begin{array}{l}\text { Years of } \\
\text { schooling }\end{array}$ \\
\hline $\begin{array}{l}\text { Years of secondary school } \\
\text { completed }\end{array}$ & $\begin{array}{l}\text { (A) Reported } \\
\text { years [o-11] }\end{array}$ & None & o & Illiterate & o \\
\hline $\begin{array}{l}\text { Vocational courses, e.g. } \\
\text { courses for tractor drivers, } \\
\text { drivers, typists, accountants }\end{array}$ & $(A)+1$ & 1-8th class & $\begin{array}{c}\text { Reported } \\
\text { years [1-8] }\end{array}$ & Primary & 3 \\
\hline $\begin{array}{l}\text { Vocational-technical school, } \\
\text { not granting secondary } \\
\text { diploma }\end{array}$ & $(A)+2$ & $\begin{array}{l}\text { Incomplete } \\
\text { secondary }\end{array}$ & 9 & Basic & 8 \\
\hline $\begin{array}{l}\text { Vocational-technical school } \\
\text { with secondary education, } \\
\text { technical school }\end{array}$ & $(A)+3$ & $\begin{array}{l}\text { Complete } \\
\text { secondary }\end{array}$ & 10 & $\begin{array}{l}\text { Secondary } \\
\text { general }\end{array}$ & 10 \\
\hline $\begin{array}{l}\text { Technikum, medical, music } \\
\text { school, school of education }\end{array}$ & $(A)+3$ & $\begin{array}{l}\text { Professional- } \\
\text { technical school }\end{array}$ & 11 & Primary technical & 11 \\
\hline Institute, university, academy & $(A)+5$ & Technikum & 13 & $\begin{array}{l}\text { Secondary } \\
\text { technical }\end{array}$ & 13 \\
\hline \multirow[t]{3}{*}{ Graduate school, residency } & $(A)+8$ & $\begin{array}{l}\text { Higher } \\
\text { educational } \\
\text { diploma }\end{array}$ & 15 & $\begin{array}{l}\text { University } \\
\text { (bachelor, } \\
\text { diploma, master) }\end{array}$ & 15 \\
\hline & & $\begin{array}{l}\text { Candidate or } \\
\text { doctor of science }\end{array}$ & 18 & $\begin{array}{l}\text { Candidate or } \\
\text { doctor of science }\end{array}$ & 18 \\
\hline & & Other & 4 & & \\
\hline
\end{tabular}

Sources: KMPS 1993, KPMS 1998, LiK 2011

1/ Reported years of both secondary and post-secondary education are used in the analysis. The presented scale is mostly applied to calculate parental years of schooling. 
Table A.4: Sample size by five-year age cohorts

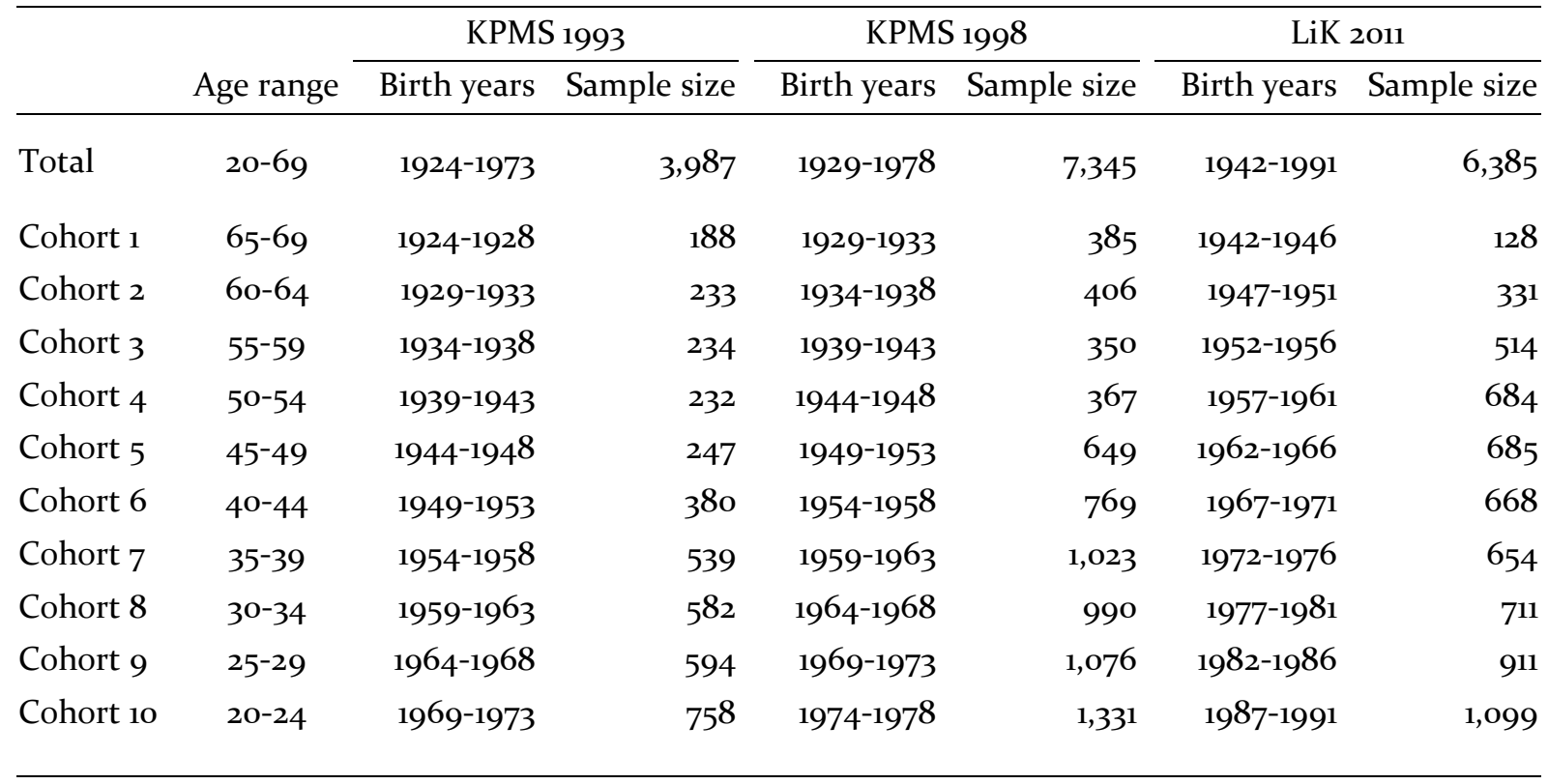

Sources: KMPS 1993, KPMS 1998, LiK 2011

Table A.5: Schooling by ethnic groups

\begin{tabular}{|c|c|c|c|c|c|c|}
\hline \multirow[b]{2}{*}{ Ethnic group } & \multicolumn{3}{|c|}{ Year of schooling } & \multicolumn{3}{|c|}{ Years of schooling of parents } \\
\hline & 1993 & 1998 & 2011 & 1993 & 1998 & 2011 \\
\hline \multicolumn{7}{|c|}{ Sample of aged 20-69 } \\
\hline Kyrgyz & 11.0 & 10.8 & 11.7 & 6.5 & $7 \cdot 3$ & 8.9 \\
\hline Uzbek & 10.3 & $9 \cdot 7$ & 10.7 & 5.2 & 5.8 & 8.2 \\
\hline Russian & 10.9 & 11.2 & 12.4 & 6.3 & $7 \cdot 9$ & $9 \cdot 5$ \\
\hline Others & 10.3 & 10.1 & 10.9 & $4 \cdot 9$ & 6.2 & 8.0 \\
\hline \multicolumn{7}{|c|}{ Sub-sample of aged $25-34$} \\
\hline Kyrgyz & 11.8 & 11.2 & 12.4 & $7 \cdot 6$ & 8.6 & 10.8 \\
\hline Uzbek & 11.1 & 10.3 & 11.0 & $5 \cdot 7$ & 6.6 & 10.5 \\
\hline Russian & 11.9 & 11.5 & 13.4 & 9.1 & 10.5 & 12.0 \\
\hline Others & 11.6 & 10.9 & 10.8 & $5 \cdot 9$ & 7.6 & 9.9 \\
\hline
\end{tabular}

Sources: KMPS 1993, KPMS 1998, LiK 2011

Note: calculations for 1998 are weighted 
Table A.6: Years of schooling based on three data sources

\begin{tabular}{|c|c|c|c|c|c|c|}
\hline & \multicolumn{2}{|c|}{1993} & \multicolumn{2}{|c|}{1998} & \multicolumn{2}{|c|}{2011} \\
\hline & Mean & Std. Dev. & Mean & Std. Dev. & Mean & Std. Dev. \\
\hline \multicolumn{7}{|c|}{ Total sample, ages 20-69 } \\
\hline Individual's years of schooling & 10.8 & 3.0 & 10.7 & 2.9 & 11.6 & 2.4 \\
\hline Parental years of schooling & 6.1 & $4 \cdot 3$ & 7.1 & 4.3 & 8.8 & 3.9 \\
\hline University educated, share & 0.14 & & 0.13 & & 0.18 & \\
\hline Age of individuals & $37 \cdot 9$ & & 38.1 & & 39.1 & \\
\hline Female, share & 0.53 & & 0.53 & & 0.52 & \\
\hline \multicolumn{7}{|l|}{ Shares by ethnic groups } \\
\hline Kyrgyz & 0.52 & & 0.59 & & 0.67 & \\
\hline Russians & 0.19 & & 0.19 & & 0.09 & \\
\hline Uzbeks & 0.15 & & 0.12 & & 0.13 & \\
\hline Other groups & 0.13 & & 0.10 & & 0.11 & \\
\hline Urban residents, share & 0.39 & & 0.41 & & 0.37 & \\
\hline \multicolumn{7}{|l|}{ Sample shares in regions } \\
\hline Bishkek city & 0.14 & & 0.19 & & 0.16 & \\
\hline Chui oblast & 0.22 & & 0.17 & & 0.18 & \\
\hline North & 0.18 & & 0.18 & & 0.17 & \\
\hline South & 0.46 & & 0.46 & & 0.49 & \\
\hline Sample & 3,987 & & 7,345 & & 6,385 & \\
\hline \multicolumn{7}{|c|}{ Young sample, ages 25-34 } \\
\hline Individual's years of schooling & 11.6 & 2.0 & 11.1 & 2.1 & 12.1 & 2.8 \\
\hline Parental years of schooling & $7 \cdot 3$ & 3.8 & 8.5 & 3.8 & 10.8 & 2.4 \\
\hline University educated, share & 0.14 & & 0.13 & & 0.27 & \\
\hline Age of individuals & 29.4 & & 29.4 & & 29.1 & \\
\hline Female, share & 0.50 & & 0.49 & & 0.51 & \\
\hline \multicolumn{7}{|l|}{ Shares by ethnic groups } \\
\hline Kyrgyz & 0.62 & & 0.64 & & 0.70 & \\
\hline Russians & 0.11 & & 0.13 & & 0.08 & \\
\hline Uzbeks & 0.16 & & 0.14 & & 0.11 & \\
\hline Other groups & 0.11 & & 0.10 & & 0.12 & \\
\hline Urban residents, share & 0.35 & & 0.40 & & 0.36 & \\
\hline \multicolumn{7}{|l|}{ Sample shares in regions } \\
\hline Bishkek city & 0.12 & & 0.18 & & 0.17 & \\
\hline Chui oblast & 0.22 & & 0.15 & & 0.19 & \\
\hline North & 0.18 & & 0.17 & & 0.16 & \\
\hline South & 0.48 & & 0.49 & & 0.48 & \\
\hline Sample & 1,176 & & 2,066 & & 1,622 & \\
\hline
\end{tabular}

Sources: KMPS 1993, KPMS 1998, LiK 2011

Note: 1998 numbers are weighted. 
Table A.7: Estimations based on educational categories

\begin{tabular}{|c|c|c|c|c|c|c|}
\hline \multirow[t]{2}{*}{ Variable / Year } & 1993 & 1998 & 2011 & 1993 & 1998 & 2011 \\
\hline & \multicolumn{3}{|c|}{ Total sample } & \multicolumn{3}{|c|}{ Young sample, aged 25-34 } \\
\hline Spearman rank correlation & 0.34 & 0.35 & 0.21 & 0.25 & 0.33 & 0.43 \\
\hline
\end{tabular}

Regression: Highest parental educational level (Secondary is a reference group)

\begin{tabular}{lcccccc} 
Primary and lower & $-1.9^{* * *}$ & $-1.8^{* * *}$ & $-0.2^{* * *}$ & $-0.6^{* * *}$ & $-0.7^{* * *}$ & $-1.1^{* *}$ \\
Basic & -0.2 & $-0.3^{* * *}$ & $-0.3^{* * *}$ & $-0.6^{* * *}$ & $-0.5^{* * *}$ & $-0.8^{* * *}$ \\
Post-secondary professional & $0.4^{* *}$ & $0.9^{* * *}$ & $1.0^{* * *}$ & $0.3^{*}$ & $0.7^{* * *}$ & $1.2^{* * *}$ \\
University & $1.2^{* * *}$ & $1.8^{* * *}$ & $2.1^{* *}$ & $1.1^{* * *}$ & $1.7^{* * *}$ & $2.8^{* * *}$ \\
Constant & $11.5^{* *}$ & $11.0^{* * *}$ & $11.2^{* * *}$ & $11.8^{* * *}$ & $11.0^{* * *}$ & $11.4^{* * *}$ \\
No of observations & & & & & & \\
Adj.R-squared & 3,942 & 7,345 & 6,385 & 1,176 & 2,064 & 1,622 \\
\hline
\end{tabular}

Sources: KMPS 1993, KPMS 1998, LiK 2011

Note: 1998 regression results are weighted. Spearman correlation is based on educational categories. In the regression, the dependent variable is the years of schooling of individuals; no other control variables are included. The regression coefficients are significant at $1 \%$ level when marked '***'; at $5 \%$ level when marked '**'; and at $10 \%$ level when marked '*'.

Table A.8: Estimations based on gender and paternal or maternal education

\begin{tabular}{|c|c|c|c|c|c|c|}
\hline & \multicolumn{3}{|c|}{ Regression coefficient } & \multicolumn{3}{|c|}{ Correlation } \\
\hline & 1993 & 1998 & 2011 & 1993 & 1998 & 2011 \\
\hline & \multicolumn{6}{|c|}{ Total sample of aged 20-69 } \\
\hline \multicolumn{7}{|l|}{ Male } \\
\hline Both parents & 0.21 & 0.20 & 0.13 & 0.33 & 0.33 & 0.22 \\
\hline Father & 0.19 & 0.19 & 0.12 & 0.33 & 0.32 & 0.22 \\
\hline Mother & 0.18 & 0.17 & 0.11 & 0.30 & 0.30 & 0.21 \\
\hline \multicolumn{7}{|l|}{ Female } \\
\hline Both parents & 0.32 & 0.33 & 0.21 & 0.44 & 0.47 & 0.33 \\
\hline Father & 0.28 & 0.30 & 0.19 & 0.42 & 0.45 & 0.31 \\
\hline Mother & 0.29 & 0.29 & 0.20 & 0.42 & 0.44 & 0.32 \\
\hline \multicolumn{7}{|c|}{ Sample of aged 25-34 } \\
\hline \multicolumn{7}{|l|}{ Male } \\
\hline Both parents & 0.13 & 0.17 & 0.49 & 0.25 & 0.32 & 0.43 \\
\hline Father & 0.12 & 0.16 & 0.39 & 0.24 & 0.31 & 0.38 \\
\hline Mother & 0.10 & 0.14 & 0.38 & 0.22 & 0.27 & 0.39 \\
\hline \multicolumn{7}{|l|}{ Female } \\
\hline Both parents & 0.13 & 0.23 & 0.50 & 0.25 & 0.41 & 0.41 \\
\hline Father & 0.11 & 0.20 & 0.42 & 0.24 & 0.37 & 0.38 \\
\hline Mother & 0.11 & 0.20 & 0.40 & 0.22 & 0.39 & 0.36 \\
\hline
\end{tabular}

Sources: KMPS 1993, KPMS 1998, LiK 2011.

Note: 1998 results are weighted. The regression specifications do not include any other control variables. All regression coefficients are significant at $1 \%$ confidence level. 
Table A.9: Estimations based on alternative groups

\begin{tabular}{llllllll}
\hline & \multicolumn{3}{c}{ Regression coefficient } & & \multicolumn{3}{c}{ Correlation } \\
\cline { 2 - 3 } \cline { 5 - 7 } & 1993 & 1998 & 2011 & & 1993 & 1998 & 2011 \\
\hline
\end{tabular}

(1) Young group extended to ages 20-34

\begin{tabular}{|c|c|c|c|c|c|c|}
\hline Aged 20-34 & $0.09^{* * *}$ & $0.18 * * *$ & $0.42^{* * *}$ & 0.18 & 0.32 & 0.37 \\
\hline Adj.R-squared & 0.03 & 0.10 & 0.14 & & & \\
\hline \# of obs. & 1,934 & 3,427 & 2,721 & & & \\
\hline
\end{tabular}

(2) Next youngest group, ages 35-44

\begin{tabular}{|c|c|c|c|c|c|}
\hline Aged 35-44 & $0.17^{* * *}$ & $0.21 * * *$ & $0.15^{* * *}$ & 0.39 & 0.34 \\
\hline Adj.R-squared & 0.09 & 0.11 & 0.07 & & \\
\hline \# of obs. & 919 & 1,749 & 1,322 & & \\
\hline
\end{tabular}

(3) Without individuals enrolled in post-secondary study

\begin{tabular}{|c|c|c|c|c|c|c|}
\hline Aged 20-69 & $0.28^{* * *}$ & $0.27^{* * *}$ & $0.19^{* * *}$ & 0.40 & 0.40 & 0.29 \\
\hline Adj.R-squared & 0.16 & 0.16 & 0.09 & & & \\
\hline \# of obs. & 3,905 & 7,176 & 6,105 & & & \\
\hline Obs.excluded, \% & 2.1 & 2.3 & 4.4 & & & \\
\hline Aged 25-34 & $0.13^{* * *}$ & $0.21 * * *$ & $0.52^{* * *}$ & 0.27 & 0.37 & 0.43 \\
\hline Adj.R-squared & 0.07 & 0.14 & 0.16 & & & \\
\hline \# of obs. & 1,160 & 2,031 & 1,598 & & & \\
\hline Obs.excluded, \% & 1.4 & 1.6 & 1.5 & & & \\
\hline
\end{tabular}

(4) Only individuals with education information for both parents

\begin{tabular}{|c|c|c|c|c|c|c|}
\hline Aged 20-69 & $0.27^{* * *}$ & $0.27^{* * *}$ & $0.18 * * *$ & 0.40 & 0.41 & $\overline{0.29}$ \\
\hline Adj.R-squared & 0.16 & 0.17 & 0.08 & & & \\
\hline \# of obs. & 3,536 & 7,234 & 6,061 & & & \\
\hline Obs.excluded, \% & 11 & 2 & 5 & & & \\
\hline Aged 25-34 & $0.13^{* * *}$ & $0.21 * * *$ & $0.53^{* * *}$ & 0.27 & 0.37 & 0.44 \\
\hline Adj.R-squared & 0.07 & 0.13 & 0.19 & & & \\
\hline \# of obs. & 1,071 & 2,029 & 1,528 & & & \\
\hline Obs.excluded, \% & 9 & 2 & 6 & & & \\
\hline
\end{tabular}

Sources: KMPS 1993, KPMS 1998, LiK 2011 